\title{
The dark side of marketing seemingly "Light" cigarettes: successful images and failed fact
}

\section{R W Pollay, T Dewhirst}

Tobacco Control 2002;11 (Suppl I):i1 8-i31

See end of article for authors' affiliations

....................

Correspondence to: Richard W Pollay, Faculty of Commerce and Business Administration, 2053 Main Mall, University of British Columbia, Vancouver, BC, V6T 1Z2, Canada;

pollay@commerce.ubc.ca
Objective: To understand the development, intent, and consequences of US tobacco industry advertising for low machine yield cigarettes.

Methods: Analysis of trade sources and internal US tobacco company documents now available on various web sites created by corporations, litigation, or public health bodies.

Results: When introducing low yield products, cigarette manufacturers were concerned about maintaining products with acceptable taste/flavour and feared consumers might become weaned from smoking. Several tactics were employed by cigarette manufacturers, leading consumers to perceive filtered and low machine yield brands as safer relative to other brands. Tactics include using cosmetic (that is, ineffective) filters, loosening filters over time, using medicinal menthol, using high tech imagery, using virtuous brand names and descriptors, adding a virtuous variant to a brand's product line, and generating misleading data on tar and nicotine yields.

Conclusions: Advertisements of filtered and low tar cigarettes were intended to reassure smokers concerned about the health risks of smoking, and to present the respective products as an alternative to quitting. Promotional efforts were successful in getting smokers to adopt filtered and low yield cigarette brands. Corporate documents demonstrate that cigarette manufacturers recognised the inherent deceptiveness of cigarette brands described as "Light" or "Ultra-Light" because of low machine measured yields.
D uring the early 1950s, scientific and popular articles presenting lung cancer research findings initiated what the tobacco industry termed the "health scare", as some consumers heard allegations about the possibility of fatal health risks. Firms initially responded to the "health scare" by introducing filtered products that were accompanied by advertisements with explicit health assertions. In time, the industry became aware that explicit health claims risked the undesirable effect of reminding consumers about health allegations and issues. To avoid this, motivation researchers and other trade analysts advised the industry to shift from explicit verbal assertions of health to subtler tactics using visual imagery and ad copy that implied healthfulness.

The first Surgeon General's report on smoking in 1964 reawakened public concerns about the potential health consequences of smoking. Tobacco manufacturers needed to reduce these consumer concerns and anxious feelings to protect their sales and profits. Quitting was not an easy or appealing option for smokers since nicotine is highly addictive, so for many smokers, switching to a lower yield cigarette became an attractive alternative once assured by advertising that so doing was a meaningful step towards health and away from risk. Thus, there was a ready market for "new and improved" cigarettes, or at least for those that seemed "new and improved".

Within this paper, we review recently released documents from the tobacco industry and its consultants for insights into the firms' thinking and actions in marketing their products over the past 50 years. The KBM Group, a contractor for the US National Cancer Institute, acted as the primary source of internal industry documents. A listing of available documents concerning low machine yield cigarettes was provided to the authors, and documents were selected for further review on the basis of relevance (according to title and subject descriptors such as marketing, advertising, consumer behaviour, and specific cigarette brand names). Using similar selection criteria, additional industry documents were accessed from the web sites created by Physicians for a Smoke-Free Canada, the Roswell Park Cancer Institute, and Anne Landman's Daily Document service. Roughly 150 separate industry documents were reviewed, all of which have been indexed and archived at the History of Advertising Archives at the University of British Columbia, Vancouver, Canada. Within this chronological review, particular attention is paid to the period of the mid 1970s when most of the current generation of low yield products were launched.

\section{EARLY FILTER PROMOTION Health protection}

Cigarette advertising during the 1950s portrayed filters as the technological fix to health concerns. These were heralded with various dramatic announcements featuring "news" about scientific discoveries, modern pure materials, research and development breakthroughs, implied endorsement from the American Medical Association (fig 1), "miracle tip filters", descriptions of "20,000 filter traps" or filters made of activated charcoal, "selectrate", "millecel", and "cellulose acetate" or "micronite" that were variously described as effective, complete, superior, and producing mildness, gentleness, smoothness, etc.

In 1958, for example, a press conference was held at New York's Plaza Hotel to launch Parliament and its new filter coined "Hi-Fi" ("high filtration", as in high fidelity state-ofthe-art sound reproduction of the 1950s). "In the foyers, test tubes bubbled and glassed-in machines smoked cigarettes by means of tubes. Men and women in long white laboratory coats bustled about and stood ready to answer any questions. Inside, a Philip Morris executive told the audience of reporters that the new Hi-Fi filter was an event of 'irrevocable significance'. The new filter was described as 'hospital white ${ }^{\prime \prime \prime}{ }^{2}$

The 1958 advertising for Parliament boasted that it "meets the standards of the United States Testing Co" (fig 2). The ad showed the official seal of the organisation which included a microscope and was readily perceived as acceptance by a government agency, although in fact it was by a private firm.

The product benefit of filtration was the perceived reduction, if not total elimination, of the cancer and other health risks being publicised from time to time. Slogans claimed or implied health like Viceroy's "Double-Barreled 


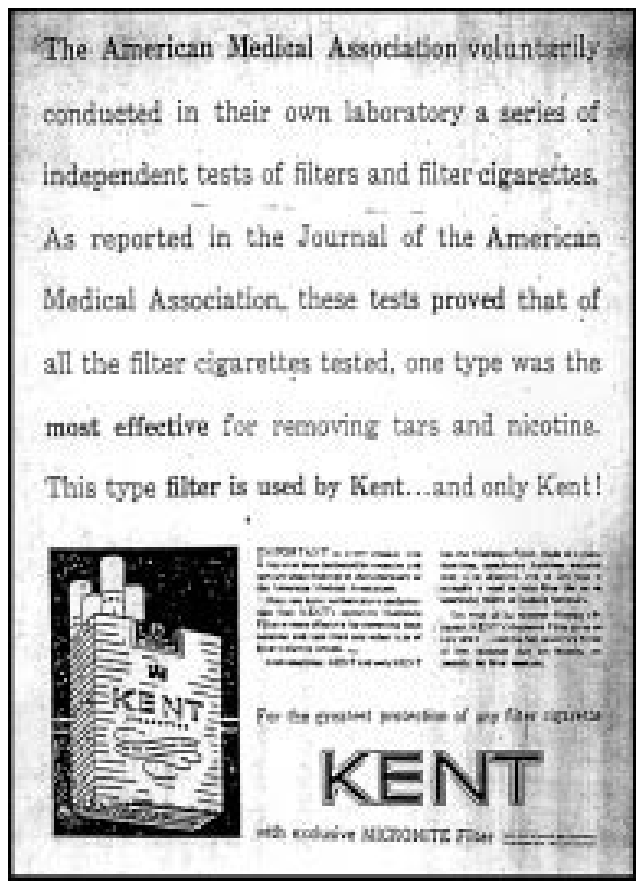

Figure 1 Kent: implied American Medical Association endorsement (circa 1953).

Health Protection", L\&M's "Just What the Dr. Ordered", Embassy's "Inhale to your Heart's Content", Life's "The Secret to Life is in the Filter", and Parliament's "Extra Margin" (of safety protection, implied by analogy to helmets, seat belts, and other safety gear). Other ad slogans, such as Viceroy's "Thinking Man's Filter" or "Delivers more of what you smoke a filter for", were even more implicit yet still begged for health inferences by consumers. ${ }^{3}$

The high technology attributes of filtration, and its ability to produce healthful conditions in other media such as water, were also communicated. "The speed with which charcoal filters penetrated the health cigarette market shows the effectiveness of a new concept. The public had been conditioned to accept the filtering effects of charcoal in other fields, and when charcoal was added to cigarette filters it proved to be an effective advertising gimmick". ${ }^{4}$

"Claims or assurances related to health are prominent in the (cigarette) advertising. These claims and assurances vary in their explicitness, but they are sufficiently patent to compel the conclusion that much filter and menthol-filter advertising seeks to persuade smokers and potential smokers that smoking cigarettes is safe or not unhealthful".5

The marketplace response was a continuation of smoking rates with a dramatic conversion from "regular" ( short length, unfiltered) products to new product forms (filtered, king sized, menthol, $100 \mathrm{~mm}$ ). "He had abandoned the regular cigarette, however, on the ground of reduced risk to health ... A further consequence of the 'tar derby' was the rapid increase in advertising expenditures during this period. Advertising expenditures in selected media jumped from over $\$ 55$ million in 1952 to approximately $\$ 150$ million in 1959."

Consumer adoption of filters in the 1950s was related to education and social class. "People who smoke filter cigarettes, have higher occupational status and income, are more consciously in conflict about smoking". ${ }^{7}$ Sex and age, however, were even more consistent predictors of who adopted the new filtered products. Women adopted filters more readily than men, and older concerned smokers more readily than young starters. ${ }^{8}$

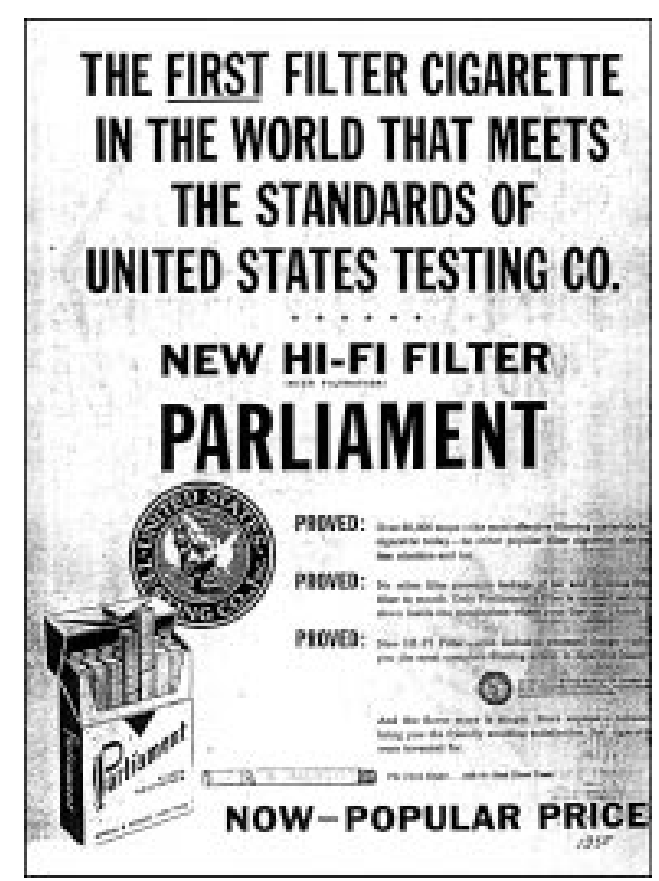

Figure 2 Parliament: endorsement of United States Testing Co (1958).

\section{Product development}

Many early brands were sold with filters that were essentially without meaningful filtration, despite appearances. According to attorneys representing RJ Reynolds (RJR), "advertising claims to the contrary aside, earlier filtered cigarettes had deliveries equal to or in excess of their unfiltered cousins". ${ }^{\prime}$

Once consumers had accepted filters as an adequate response to at least assuage their worst fears, there was a market opportunity in providing men with filtered products that continued to deliver "full flavour". Some industry internal documents from the 1970s portray the filters of the 1950s as merely "cosmetic" and noted that "once the consumer had been sufficiently educated on the virtues of filters, a vacuum was created for a filter with taste; [and] this vacuum was filled by Winston and Marlboro"..$^{10}$

The period from the mid 1950s until the mid 1960s was tumultuous for the industry, with many new filter products launched, many competitive advertising claims using different standards of measurement, changing Federal Trade Commission (FTC) guidelines about what was or was not permitted in cigarette advertising, and occasional news about research findings affecting the marketplace. Intense rivalry regarding claims and counter-claims about cigarette yields were dubbed the "tar derby" or "tar wars" within the trade.

Some manufacturers took advantage of these dynamics to establish themselves in the public mind as "healthy" during a period of intense advertising claims, and then capitalised on that reputation while selling product that was actually quite high in its tar and nicotine yield. Kent, for example, whose asbestos based "Micronite" filter had originally been much touted as very effective, engaged in a series of product revisions in the 1950s and early 1960s. With each iteration, the Kent product yielded increasingly more tar and nicotine. Similar filter "loosening" was the subject of US Congressional inquiry. That investigation, in 1958, also found reversals in which some firms' filtered products delivered even more tar and nicotine than their unfiltered traditional products. Reversals even occurred within brand families, with Brand $X$ filtered versions yielding higher tar and nicotine than the unfiltered Brand X products they seemed to improve upon. ${ }^{11}$

During this "tar derby" period of the later 1950s, new menthol filtered products were also introduced such as Newport, 


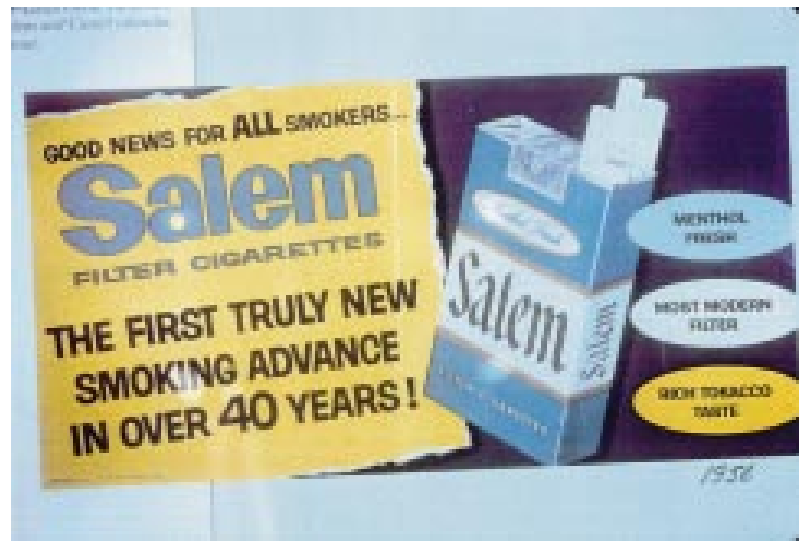

Figure 3 Salem: "First Truly New Smoking Advance" (1956).

Oasis, and Salem (fig 3). These capitalised on the reputation menthol had within cough and cold remedies, and the history of health claims made by earlier advertising for unfiltered menthol brands like Spuds and Kool. "Menthol styles were perceived as healthier, low ' $\operatorname{tar}^{\prime}$ smokes due to the quasimedical health claims in menthol advertising". ${ }^{12}$

"Kool not only remained, but was actively positioned as a remedial/medicinal type product throughout the 1950's . .

Salem created a whole new meaning for menthol. From the heritage of solves-the-negative-problems-of-smoking, menthol almost instantly became a positive smoking sensation. Menthol in the filter form in the Salem advertising was a 'refreshing' taste experience. It can be viewed as very 'reassuring' in a personal concern climate. Undoubtedly, the medicinal menthol connotation carried forward in a therapeutic fashion, but as a positive taste benefit". ${ }^{13}$

\section{CANCER CONCERN BECOMES OFFICIAL}

The first Surgeon General's report on smoking and health in 1964 indicted the cigarette for its role in inducing lung cancer. This made industry members aware of the profit opportunities inherent in products and advertising that made some cigarettes appear healthier. Philip Morris, however, wished that the Surgeon General had been a stronger endorser of filtered products. "The health value of filters is undersold in the report and is the industry's best extant answer to its problem. The Tobacco Institute obviously should foster the communication of the filter message by all effective means". ${ }^{14}$

\section{Consumer guilt and anxiety}

Philip Morris anticipated that women would be the largest potential market for a "health cigarette" following the release of the 1964 Surgeon General's report. ${ }^{15}$ Consumer research conducted for Brown \& Williamson (B\&W) recognised consumers' addiction psychology, as well as their conflicts, guilts, anxieties, and needs for reassurance.

"Most smokers see themselves as addicts ... the typical smoker feels guilty and anxious about smoking but impotent to control it". "Psychologically, most smokers feel trapped. They are concerned about health and addiction. Smokers care about what commercials say about them. Advertising may help to reduce anxiety and guilt" [emphasis in original]. "[Smokers] may be receptive to advertising which helps them escape from their inner conflicts about smoking". ${ }^{16}$

"While unquestionably smokers are concerned about the tar and nicotine contents and the filtration effectiveness of their brands, nevertheless, both on the surface and even to some extent unconsciously, they appear to be resisting open involvement with this 'frightening' element of smoking". ${ }^{17}$ Some brands were less successful than others when trying to address consumer conflicts directly. Kent, for example, used a

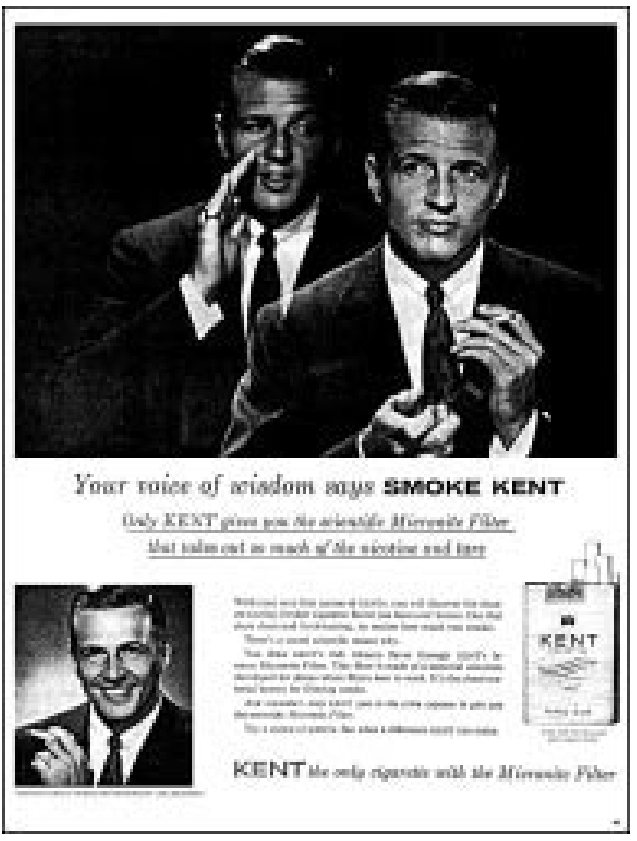

Figure 4 Kent: "Voice of Wisdom" (1955).

visual portrayal of a smoker's conscience, and thus risked being experienced as guilt inducing rather than guilt reducing (fig 4).

In order to provide a "foundation upon which marketing and advertising executions can be built", Lorillard did a market segmentation analysis which identified clusters of consumers with similar psychologies. The consumer segment most appropriate for Kent was described in substantial and subtle psychological detail. Despite the label of "social conformist", the central concern of these smokers was health consequences.

"Compared with the rest of the market, Segment B is less concerned about smoking enjoyment and more concerned about the health aspect of cigarettes. He cares particularly about a cigarette's filter, its king size, and its association with health ... The other psychological requirement of Type B is the need for social benefits through association with 'educated moderns' . . .educated moderns' include the active, modern people, college graduates, and professionals such as lawyers, doctors, etc" ${ }^{18}$

\section{The "illusion of filtration"}

In their 1966 analysis of the market potential for a "health


proportion of smokers had health concerns, they could be assuaged by products whose filtration was largely an illusion. The report emphasised: "1. A large proportion of smokers are concerned about the relationship of cigarette smoking to health ...9. Mere reduction in nicotine and TPM [total particulate matter] deliveries by conventional methods of filtration would not be a sufficient basis for launching a new cigarette. 10. The illusion of filtration is as important as the fact of filtration. 11. Therefore any entry should be by a radically different method of filtration but need not be any more effective". "A cigarette that does not deliver nicotine cannot satisfy the habituated smoker and cannot lead to habituation, and would therefore almost certainly fail". ${ }^{19}$

\section{Nicotine weaning feared}

There was a shared concern that reducing the delivery of nicotine to consumers might have the "self defeating consequences" of weaning them away from smoking and letting them off the nicotine hook. "In its search for 'safer' 
cigarettes, the tobacco industry has, in essentially every case, simply reduced the amount of nicotine ... perhaps weaning the smoker away from nicotine habituation and depriving him of parts of the gratification desired or expected ... Thus, unless some miraculous solution to the smoking-health problem is found, the present 'safer' cigarette strategy, while prudent and fruitful for the short term, may be equivalent to long term liquidation of the cigarette industry". ${ }^{20}$

"Taking a long-term view, there is a danger in the current trend of lower and lower cigarette deliveries-i.e. the smoker will be weaned away from the habit ... Nicotine is an important aspect of 'satisfaction', and if the nicotine delivery is reduced below a threshold 'satisfaction' level, then surely smokers will question more readily why they are indulging in an expensive habit". ${ }^{21}$

By 1973, it was clear to industry participants that a significant number of brands shared characteristics leading them to be described as a "new low delivery segment". Precise definition was made difficult, in part because some brands like Kent and Parliament were perceived by consumers as being low in delivery because of their product and advertising histories, even though they were no longer in fact low delivery. Philip Morris used multiple criteria in defining the category, but noted that no matter what the technical specifications, "consumer opinion should be the ultimate criterion for market segmentation". ${ }^{22}$

\section{Nicotine delivery}

During the early 1970s, Philip Morris was internally expressing confidence in its ability to selectively reduce tar yield while continuing to deliver the all-important nicotine. "[T] he tar deliveries of the currently best selling cigarettes might be reduced somewhat, leaving nicotine as it is, without any significant overall decrease in the cigarettes' acceptability". ${ }^{23}$ RJR was following a similar line of thought in focusing its product development on nicotine delivery. "If nicotine is the sine qua non of tobacco products and tobacco products are recognized as being attractive dosage forms of nicotine, then it is logical to design our products-and where possible, our advertising-around nicotine delivery rather than 'tar' delivery or flavor" [emphasis in original]. ${ }^{24}$

One tactic RJR adopted in 1975 was the use of $\mathrm{pH}$ adjustments affecting nicotine bioavailability. "The primary concern was to produce a certain effect, i.e. physiological strength in conjunction with low 'tar' delivery. This effect was achieved mainly by using puffed tobaccos and by adjusting smoke $\mathrm{pH}$ and nicotine delivery". ${ }^{25}$

By 1976, the RJR Market Research Department (MRD) had joined the Research and Development (R\&D) effort with a clear statement of their intent to maximise the nicotine satisfaction while maintaining high profitability by using conventional filters and packaging. "MRD and R\&D have been working on a sophisticated consumer product testing program to help us ensure that we select the best blend alternative for our brands to optimize physiological satisfaction". "Our top priority is to develop and market low 'tar' brands ( 12 MG. 'tar' and under) that: Maximize the physiological satisfaction per puff-the single most important need of smokers ... [and] yield higher profitability which means conventional filters and soft packaging for high speed production efficiencies". ${ }^{26}$

A few years later, in 1981, British American Tobacco, the parent to B\&W, wrote that "effort should not be spent on designing a cigarette which, through its construction, denied the smoker the opportunity to compensate or oversmoke [sic] to any significant degree" [emphasis added]. ${ }^{27}$

\section{Consumer psychology and ignorance}

As in the 1950s, it was women and older, health concerned smokers who most readily adopted the new, seemingly low yield products of the 1960s and 1970s. "The modern low 'tar' market began in the 1960's with such brands as True, Carlton, and Doral . . . initial gains were from females and older smokers ... The hi-fi smoker demographics tend to be female, older, and have switched from a full flavor style to its counterpart in the hi-fi segment" ${ }^{28}$

This was so much the case that the men who smoked these lowest yield products were suspect of being "weak men" in the eyes of consumers studied for B\&W. ${ }^{29}$ This echoed their research finding in the 1960s that the men who smoke filters were "apprehensive and depressive. They think about death, worry over possible troubles, are uneasy if inactive, don't trust others". ${ }^{30}$ In 1974, advertising agency advisors to Lorillard tried to counter this problem with a style of advertising for the True brand that they felt had more "masculine, 'macho' tonality and appeal. Vantage's tonality can be described as 'laying it on the line' in an aggressive, possibly masculine, open fashion". ${ }^{31}$

This problem of low yield products being perceived as highly feminine seems to have led RJR to desire a marketing strategy that placed "balls (two of them)" on a low yield cigarette they were developing in 1976. "What we want is to portray the feeling and image projected by Marlboro and Kool advertising on a Vantage/Merit type of cigarette. In other words, put 'balls' (two of them) on a low 'tar' and nicotine cigarette and position" [parenthetical clarification of the male genitalia meaning of "balls" in original]. ${ }^{32}$

During the 1970s, additional evidence of consumer confusion, misinformation, rationalisations, and the corresponding role played by advertising was gathered by multiple firms. Market researchers for the industry and its advertising agencies were not even confident that consumers knew what they were talking about when referring to the "taste" of a cigarette. "[I]t is almost impossible to know if the taste smokers talk about is something which they, themselves attribute to a cigarette or just a 'play-back' of some advertising messages". ${ }^{33}$

Even the "taste" of a product is greatly influenced by the brand's image and reputation. Merit, as a free-standing brand, had difficulties in being perceived as flavourful, whereas in contrast, product line extensions like Marlboro Lights had the advantage of being perceived as more flavourful due to the taste reputation of the "parent" brand. ${ }^{34}$

In 1974, Kenyon \& Eckhardt Advertising studied young "recently starting smokers" for B\&W. "Health concerns exist among younger smokers ... One type of smoker rationalized smoking as a pleasure that outweighed the risks. Another felt that they didn't smoke enough to be dangerous. A third type rationalized his use of cigarettes by feeling he would quit before it was 'too late.' A final smoker group said that science would come to his rescue ... In talking to these young smokers about the different brands of cigarettes they have smoked, we found that they have little knowledge and, in fact, a great deal of misinformation on brand yields. In all of the sessions, not a single respondent know [sic] the tar and nicotine level of the cigarette he or she smoked". ${ }^{35}$

Lorillard and their ad agency had the same experience when studying consumers for Kent. They, like B\&W, found that "practically no one knew" the tar content of their own regularly smoked brands. ${ }^{36}$ Philip Morris, too, knew about this consumer ignorance of yields in the 1970s. Despite the faith in the technology of filters displayed in their shifting to filters and hi-fi products, most consumers were not only ignorant of the facts, but even their general impressions were not very good. "As yet, there is low awareness among smokers of the tar content of their brand. When asked if they knew the specific milligram tar content of their brand, the vast majority $(89 \%)$ said they didn't know ... smokers' impressions of whether their brand has high, moderate or low tar content is more on the mark-although still not too accurate" [emphasis in original $].^{37}$

Consumers' conflicted feelings were such that they became poor respondents in B\&W's research efforts. "[S]mokers 
themselves falter badly when asked to comment on the rewards accruing to them from smoking ... Smokers are so overwhelmed by the addictive properties of cigarettes and the potential health hazard that they wax virtually inarticulate when asked to present a case for the other side. They become guilty and shame-faced". ${ }^{38}$ "Smokers own estimates of their daily consumption levels are extremely unreliable. Many smokers underestimate their actual consumption and certain segments of many populations, notably young people and women, are often reluctant to admit they smoke".$^{39}$

B\&W blamed consumer confusion on advertising, in part. When contemplating a possible "index of safety" (cf an "index of danger") for cigarettes, B\&W commented that: "Such an index would have merit for the health-conscious smoker, who otherwise may well become confused and increasingly dismayed if one alleged hazard follows another, coupled with the manufacturers' 'prescription for health' through advertising". ${ }^{40}$

Additional market research conducted for B\&W and its ad agency, Ted Bates, indicated that advertisements needed to be carefully designed, lest they challenge consumer denials and rationalisations and trigger consumer defensiveness. Because of this defensiveness, cigarette advertising, like political speech, is the art of ambiguity into which each consumer can project their individual needs. "[S]mokers have to face the fact that they are illogical, irrational and stupid ... while an ad that depicts an exciting, invigorating situation could be interesting to the smoker-viewer, the very thin line separating positive excitement from negative-creating situation should never be crossed . . . communication with the smoker that either directly or indirectly violates and belittles this rationalized need will meet smoker's objection-it destroys the rationalization and the smoker would feel naked and rather stupid". "There are not any real, absolute, positive qualities and attributes in a cigarette and no one, even the most devout smokers, could believe any glorification or lies about it ... The more a cigarette ad is disbelieved, the more it 'fights' the defense mechanism of the smoker-the more the smoker feels challenged ... The picture, situation presented and the copy should be ambiguous enough to allow the reader to fill-in his/ her illogical-logic which are the results of each individual defense-mechanism" [emphasis in original]. ${ }^{41}$

As RJR put it more recently and more bluntly, the smoker of low tar products "wants nothing less than to be conned with information". ${ }^{42}$ Essential, however, was that low yield cigarette brands appeared to be a healthier alternative, even if this was an image or illusion, and even if the manufacturing technology did not yet allow for the control of smoke toxicity. In 1976, a British American Tobacco planning document wrote: "Looking further down the road, the possibility exists that . . f filters might offer a selective means of controlling smoke toxicity. Well before that date, however, opportunities exist for filter and cigarette designs which offer the image of 'health re-assurance ${ }^{\prime \prime}$ [emphases added ${ }^{43}$

\section{Case histories}

Merit

Philip Morris had seen the competitive value of a so-called "health cigarette" following the first Surgeon General's report on cigarettes in 1964. Over the course of the next 12 years Philip Morris worked on such a product, culminating in the 1976 product launch of the Merit brand. One key tactic was to "enrich" the product by applying extensive efforts in flavour chemistry and additives (fig 5). Philip Morris seemed proud of the fact that they had managed this while using "less than 100 flavorants" . ${ }^{44}$ While the advertising did boast about the product being "enriched", it did not disclose any of these less than 100 flavouring chemicals to consumers.

The market launch strategies gave particular emphasis to the choice of the name Merit, obviously communicating apparent virtue, and an advertising style that made this product development seem eminently scientific and newsworthy and less like an ad. The product launch strategy included a record level of advertising investment.

"The advertising was designed to overcome the low interest level in cigarette advertising, to communicate the technological breakthrough which MERIT represented and to report the impressive results of the taste testing program. To achieve these goals, a bold and aggressive strategy was devised featuring headlines and ads that had scientific substance and validity ... The ads were written in a journalistic, repertorial [sic] style to be precise, pointed, and absolutely believable ... This strategy entailed a multi-media blitz aimed at a broad range of smokers. It required a major commitment by Philip Morris USA to a high level of media investment. Newspapers and magazines were utilized nationwide to get the complete product story to consumers. Massive outdoor billboard displays, subway signs, taxi-tops and exterior bus posters would be used to create brand awareness. The displays utilized straightforward graphics which were designed to provide sufficient visibility to give high spontaneous retail sales". ${ }^{45}$

"Merit was the primary focus of the sales force for a full year ... We spent $\$ 45$ million on advertising-remember $\$ 45$ million in 1976! This was a record amount for a new brand introduction ... Creatively, we used provocative headlines and important looking copy which looked like it had real news value. Tar/taste theory exploded! - Smoke cracked! - Taste barrier broken!" [emphasis in original]. ${ }^{4}$

"The bold national launch of Merit by Philip Morris jolted the cigarette industry as few product introductions have. Full page newspaper ads trumpeted the arrival ... the beginning of a blitz in all media that still has the competition muttering to itself. Industry insiders estimated that when media, point-ofpurchase, promotion and collateral are totalled for the year, the sum will stand close to $\$ 50$ million. Others suggest the roll-out of Merit is the most expensive new product introduction in the history of the cigarette industry". ${ }^{47}$

Fact

B\&W's introduction of the Fact brand was described by a company spokesperson as "a typical new product introduction



Figure 5 "Merit Science Works-Enriched Flavour" (1979). 


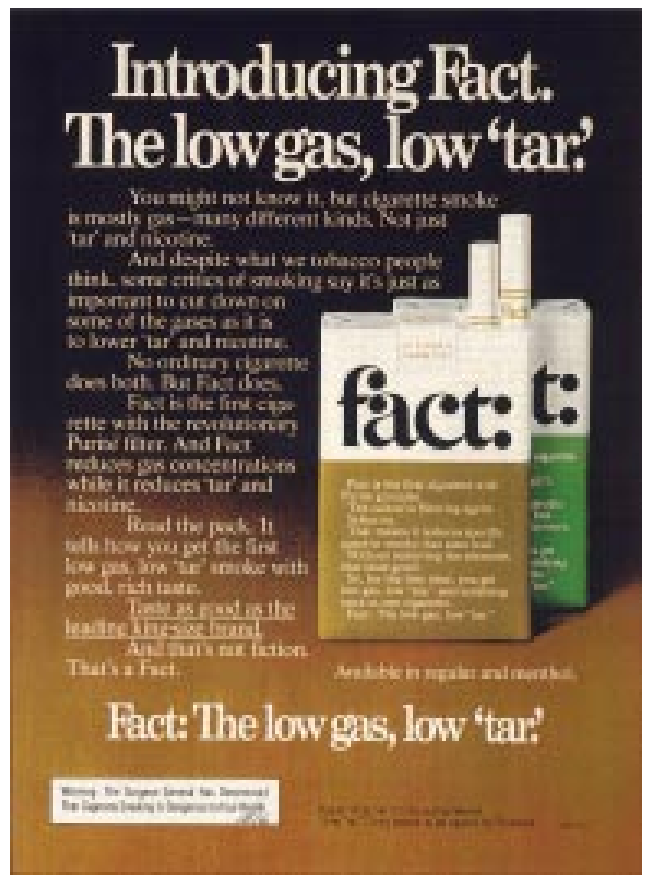

Figure 6 "Introducing Fact. The low gas, low 'tar'".

as compared to Philip Morris' sudden national blitz for Merit ... Fact is directed to the educated, concerned smoker. Our copy is straightforward and direct, and there is no gender differentiation or symbolism" ${ }^{48}$ Fact was using the Purite filter to filter gases from the smoke column, but needed to first inform consumers that gases were an issue. Their initial effort was test-marketed, but did not perform well in the marketplace, despite advertising support of about $\$ 30$ million over 1976-77 (fig 6). The senior brand manager of B\&W explained: "The low gas benefit of the product wasn't of interest to the public, and wasn't understood. The advertising and packaging failed to reinforce the flavor aspect of the brand ... The package was perceived by customers as medicinal, like a prescription bottle of Geritol. The tar level wasn't low enough by mid-1976 to allow it to be a talking point in advertising". ${ }^{49}$

B\&W's reconsideration of its Purite gas filter recognised that in having to educate consumers about gas in smoke, they might raise more anxiety than they could resolve with this type of product. "While low gas does offer the opportunity to make positive health statements to active and passive smokers alike, it does run the category risk of raising another health issue and perceptively offering lower taste/satisfaction" ${ }^{\prime 50}$

$\mathrm{B} \& \mathrm{~W}$ gave the brand another try, nonetheless, because they had a brand name they liked, had some established brand recognition, and had developed channels of retail distribution. B\&W's new brand manager was thorough in specifying marketing objectives and media requirements for its ad agency. His media planning document gave them "awareness/ trial goals for the brand, demographic characteristics of the target audience, with weights, special creative requirements, budget limitations and seasonal spending patterns" ${ }^{51}$ They earmarked \$20 million for 1978, this time trying to sell Fact as a "full flavor" cigarette. "Full flavor smokers would be comfortable with Fact as positioned by models in ads. Previously, Fact users were seen as older, up-scale and academic". ${ }^{52}$ The new re-positioned effort showed a model, Dave Morris, in a cardigan with the headline, "I'm realistic. I only smoke Facts" (fig 7). Unfortunately, the public never learned the essential fact that Dave Morris became painfully paralysed when lung cancer spread to his brain and spine before he died..$^{33}$

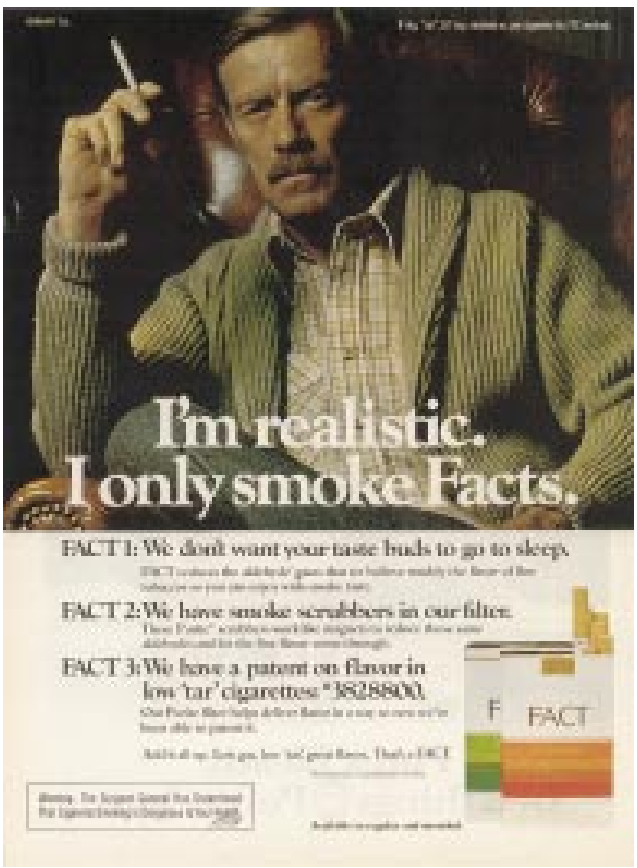

Figure 7 "I'm realistic. I only smoke Facts".

Real

RJR's 1976 assessment for their three year action plan acknowledged that they were not yet as capable as desired in producing products which had reduced tar without the undesirable effect of also having reduced nicotine. "In general, methods used to reduce 'tar' delivery in cigarettes lead to a proportionate reduction in nicotine ... It would be more desirable from our standpoint, i.e. providing satisfaction to the smoker and maintaining his allegiance to smoking if we could reduce 'tar' to whatever target we choose without a proportionate drop in nicotine ... It will take some time to get there by the approaches we visualize" ${ }^{54}$

Nonetheless, RJR wanted to participate in the rapidly expanding category of concerned consumers, referred to by RJR as "worriers". RJR's product offering was the Real brand, with a "natural - no additives" claim (fig 8). This "natural" position was thought to convey positive messages to both full flavour smokers and those seeking effective filtration and health protection. The Real concept was described as having "broad appeal based primarily on 'natural'/no additives claim. Connotes taste to full flavor smokers, low numbers to hi-fi smokers. No significant negatives". ${ }^{55}$

When the Real brand was launched by RJR in 1977, it had a budget of $\$ 40$ million for "boxcar loads of display materials, more than 25 million sample packages, the biggest billboard overlooking Times Square, the summer long services of 2,000 salesmen ... and advertising, according to the agency running the campaign, on everything but painted rocks". Just as no effort had been spared in finding advertising media for Real, no effort was spared in seeking security and secrecy, including the release of intentionally false information. "Papers were distributed behind sealed doors, kept in locked drawers, handled by staff with special clearances, and tossed into shredders ... false bits of information were put out to deceive the prying public and the competition." A Ritchy, project director for RJR, stated, "We used all the techniques of military intelligence". ${ }^{56}$

Now

The manager of the RJR's Now brand conceived of the targeting effort, not as a shotgun strategy aimed at a mass market, but as a more focused rifle targeting (fig 9). "We played to the 


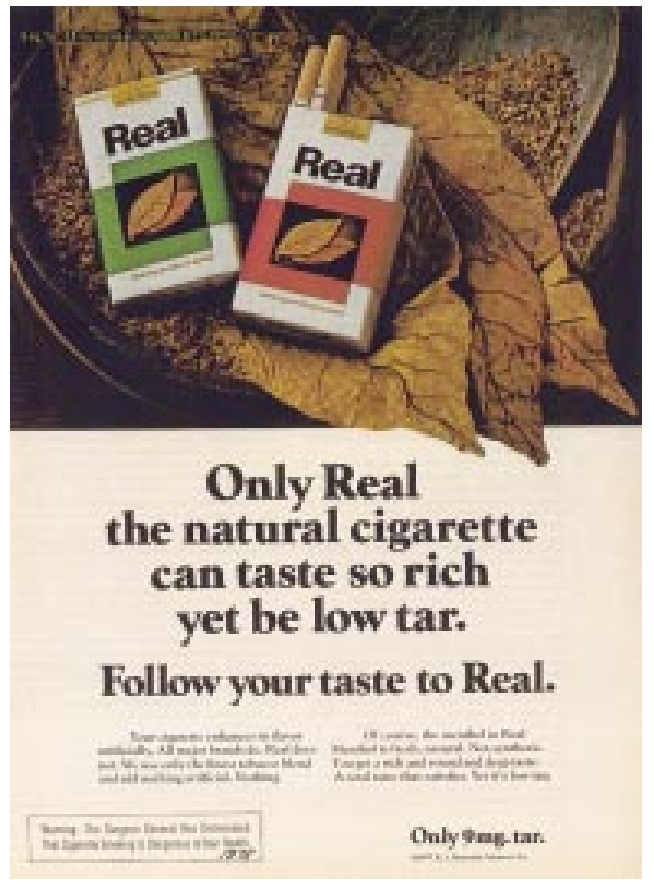

Figure 8 Real "Natural" (1977).

special needs of smokers ... NOW: Lowest tar and sophistication. Our efforts were highly targeted in terms of advertising copy, media, point-of-sale, and consumer sampling ... Against the highly concerned urbane smoker". ${ }^{57}$

\section{Camel Lights}

The high stakes in the competition within the cigarette trade led to extensive testing of new products and their marketing before committing to full deployment. The care with which even line extensions of familiar products were executed is seen in the efforts of RJR in preparing to introduce Camel Lights. This new product variation was tested in six cities in a multivariable experimental design testing three advertising

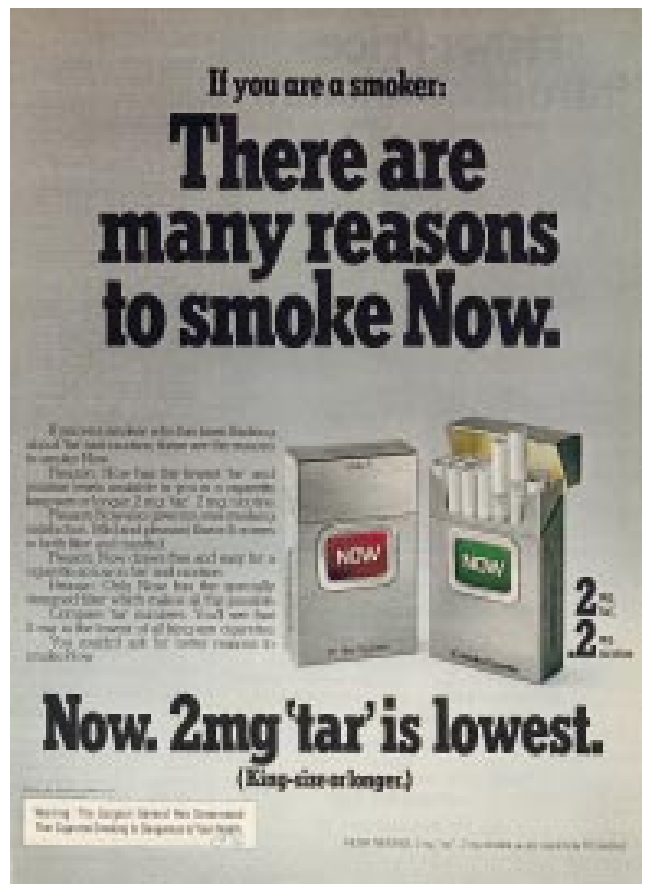

Figure 9 "There are many reasons to smoke Now" (1976). concepts, four package designs and two levels of ad spending, equivalent to $\$ 15$ and $\$ 29$ million on a national basis. With the stated goal of wanting "Camel to escape its older, masculine, downscale imagery", three brand positionings were tried: "slightly masculine, modern and upper-middle class". ${ }^{58}$

\section{Winston Light 100s}

When promoting its Winston Light 100s in 1978, RJR placed emphasis on the distribution of product samples to complement its advertising. This promotional effort generally sought to influence consumer perceptions, with focus placed on the brand users and the taste dimensions of the product. "WINSTON LIGHT 100's Promotion Plan. Promotion Objectives ... Image Perceptions Desired: A user image which is feminine, contemporary, style conscious, young-at-heart, sensitive and relatively sophisticated". ${ }^{59}$

\section{MARKETING AND ITS CONSEQUENCES Advertising budgets}

The advertising spending for new low yield products from 1976 to 1978 was awesome and commanded a very disproportionate share of the firms' total advertising budgets-shareof-voice (SOV). Contemporary advertising trade accounts described this promotional flurry as "a numbers game that boggles the mind while promising to relieve the lungs" ${ }^{60} \mathrm{New}$ brands and product line extensions (variations of familiar brands) were introduced with major budgets as shown in the box below. ${ }^{6}$

"The phenomenal growth of hi-fi brands is, in part, a self-fulfilling prophecy. Hi-fi expenditures have grown from $7 \%$ SOV in 1972 to $45 \%$ in 1977 , much faster than actual segment growth". ${ }^{2}$ " [T] he low tar revolution [of 1976ff] is not ignited by a particular event, such as a Reader's Digest article, a Surgeon General's Report, etc.; it happens quietly based on technologically improved products and consumers' desire for a reasonable compromise and the industry's massive advertising support leading category development" ${ }^{63}$

\section{Packaging and press relations}

Packaging design is important in affecting consumer perceptions of relative safety, and even taste. "Red packs connote strong flavor, green packs connote coolness or menthol and white packs suggest that a cigaret [sic] is low-tar. White means sanitary and safe. And if you put a low-tar cigaret [sic] in a red package, people say it tastes stronger than the same cigaret [sic] packaged in white" ${ }^{64}$

Not surprisingly, then, most "Light" and "Ultra Light" cigarettes are in predominately pale or white packaging with minimal adornments, albeit not all are. RJR gave Now a "modern, chrome-and-glass look designed to appeal to upscale city and suburban dwellers". Philip Morris' successful Merit connotes a "flamboyant, young-in-spirit image" (to offset low-tar's dull image) with big yellow, brown, and orange racing stripes. ${ }^{64}$

To supplement and reinforce their advertising efforts, B\&W conceived of public relations and political activities so that consumers would see apparently independent endorsements

\section{Advertising budgets for the new low yield products}

$\begin{array}{ll}\text { Merit } & 44 \text { million } \\ \text { Now } & \$ 23 \text { million } \\ \text { Fact } & \$ 20 \text { million } \\ \text { Real } & \$ 29 \text { million } \\ \text { Decade } & \$ 24 \text { million } \\ \text { Camel Lights } & \$ 25.3 \text { million } \\ \text { Carlton } & \$ 15.3 \text { million } \\ \text { Vantage } & \$ 20.6 \text { million } \\ \text { Golden Lights } & \$ 21.0 \text { million } \\ \text { Marlboro Lights } & \$ 20.1 \text { million }\end{array}$

$(1976)$
$(1976)$
$(1976)$
$(1977)$
$(1977)$
$(1978)$
$(1976)$
$(1976 / 1977)$
$(1976-1978)$
$(1976-1978)$


of low yield products. This would reinforce advertising impressions about the virtues of low tar products with seemingly independent "news" from credible sources. "B\&W will undertake activities designed to generate statements by public health opinion leaders which will indicate tolerance for smoking and improve the consumer's perception of ultra low 'tar' cigarettes ( $5 \mathrm{mg}$. or less) ... Through political and scientific friends, B\&W will attempt to elicit ... statements sympathetic to the concept that generally less health risk is associated with ultra low delivery cigarette consumption" ${ }^{65}$

\section{Capturing consumer concerns}

During all of this promotional activity, many consumers considered, tried, and even switched to the nominally lower yield products, and did so primarily in pursuit of better health. When asked if and why some brands were thought to be better for health, smokers showed that they had bought the idea that the nominally low yields were meaningful.

"More people have switched brands in the past year, and the largest group of switchers have gone to low tars. Even among those who have not switched to a low tar brand, there is fairly high disposition among smokers to consider switching to one. This is probably attributable to the continuing concern over smoking and health". "The low tar brands have cornered opinion that to the extent any brands are better for your health, they are ... The brands named were almost exclusively low tar brands, with the older low tar brands (Vantage, True, and Carlton) getting most mentions. Considering the short length of time they have been on the market, both Merit and Now had comparatively good mention ... it is the lower tar content of these brands that make people say they are better for health. When asked why the brands they named were better for your health, answers overwhelmingly were concerned with lower tar content" ${ }^{66}$

When the motivations for smoking ultra low tar cigarettes were studied by Philip Morris' contractors in 1978, representatives of the Brand Management Group, Marketing Research Department, and the advertising agency observed the discussion groups from behind a two way viewing mirror. All of the motives elicited specific to this product form were health related. "[W]ith respect to ultra low tar brands there appear to be particular additional motivations for smoking this type of cigarette. These include: A-Voluntary desire for a safer cigarette. $\mathrm{B}$-Increasing awareness and concern about possible hazards of smoking. C-Health problem forcing a change to a safer cigarette (as an alternative to not being able to quit). D-Peer and family pressure to smoke a safer cigarette (as an alternative to not being able to stop smoking). E-Mental commitment to do something about smoking habits". ${ }^{67}$

The reassurance of apparent low yields led many to switch rather than quit. "It is useful to consider lights more as a third alternative to quitting and cutting down-a branded hybrid of smokers' unsuccessful attempts to modify their habit on their own". ${ }^{68}$ "In point of fact, smoking an ultra low tar cigarette seems to relieve some of the guilt of smoking and provide an excuse not to quit". ${ }^{69}$ True's campaign in the 1970s spoke directly to the desire to quit, portraying quitting and smoking True as equivalent alternatives ( fig 10).

\section{Lessons learned about marketing}

Tobacco manufacturers saw advertising, and marketing efforts more generally, as vital to how consumers perceived the product, themselves, and ultimately how well various firms succeeded. Lorillard listed the psychological role of marketing as key, right alongside of the product's capacity to deliver the physiological stimulation of nicotine. "[L]et me try to define the elements of product acceptance (given sales distribution and trial) as they relate to tobacco products ... The value or price of the product is a factor . . . The second element in acceptance is psychological. One principle component of this element arises from our marketing effort ... The third element in acceptance is physiological, being comprised largely of the nicotine-induced stimulation". ${ }^{70}$

RJR wanted advertising that affected the ways in which consumers saw themselves and presumed themselves to be perceived by others (that is, "Products targeted to social symbolism and enhancing social acceptability of cigarette smoking"). ${ }^{71}$ In 1976, RJR briefed their ad agency, Ogilvy $\delta$ Mather, with the following summation of the importance of advertising which provided psychological symbolism to consumers. "[T]here are the traditional needs which form the very basis for the cigarette industry's existence. These are primarily physiological responses-the primary reason for people smoking. I refer to nicotine. And, as marketers, we cannot lose sight of the secondary traditional needs of consumers . . social symbolism, virility, status, etc. which is depicted by appropriate advertising". ${ }^{72}$

B\&W clarified that this social symbolism was not reflecting reality for smokers, but rather the dream world they aspired to. "Successful cigarette brands have established and maintained consistently over time distinctive brand personalities ... Role of cigarette marketing is establishing and managing of a distinctive image ... Recognize that successful campaigns create a world to which the consumer aspires with the cigarette serving as an enabling device to access that world. Association with this world is both pleasurable and aspirational.".73

B\&W articulated the dual objectives of good advertisingproviding reassurance about healthfulness (without, of course, doing so in a heavy handed way to induce defensiveness) and also providing a socially attractive brand image the smoker could acquire when buying and displaying the package. "Good cigarette advertising in the past has given the average smoker a means of justification on the two dimensions typically used in anti-smoking arguments: 1. High performance risk dimension ... 2. Ego/status risk dimension...For some smokers reduction in physical performance risk is paramount, for others reduction in 'ego/status' risk comes first . . . All good cigarette advertising has either directly addressed the anti-smoking arguments prevalent at the time or has created a strong, attractive image into which the besieged smoker could withdraw" [emphasis in original]. ${ }^{74}$

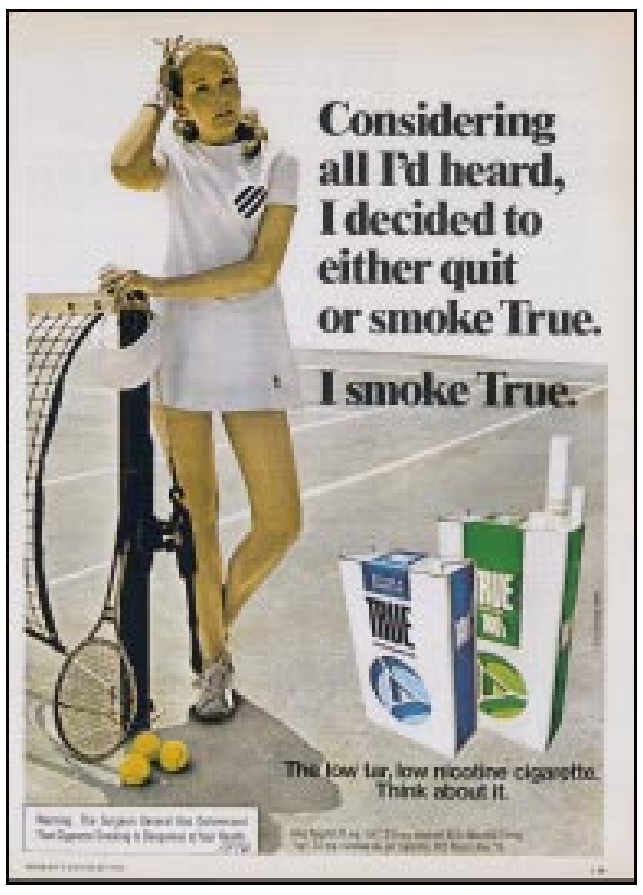

Figure 10 Quit or smoke True as equivalent options (1976) 
The international headquarters of B\&W's parent firm, British American Tobacco, counselled that new marketing approaches should "create brands and products which reassure consumers, by answering to their needs. Overall marketing policy will be such that we maintain faith and confidence in the smoking habit . . All work in this area [communications] should be directed towards providing consumer reassurance about cigarettes and the smoking habit ... by claimed low deliveries, by the perception of low deliveries and by the perception of 'mildness'. Furthermore, advertising for low delivery or traditional brands should be constructed in ways so as not to provoke anxiety about health, but to alleviate it, and enable the smoker to feel assured about the habit and confident in maintaining it over time" [emphasis in original $].^{75}$

\section{Policing deceptive practices \\ Triumph}

Effective policing of deceptive advertising of low tar products came from competitors, rather than the FTC or any other agency. In one case, Lorillard used data from a taste comparison test to imply a consumer preference for its Triumph brand. The Lorillard survey showed 36\% favoured Triumph over Merit, 24\% rated them even, and 40\% favoured Merit when preferences were obtained after subjects knew the products' tar levels). The enjoined statement took advantage of the $24 \%$ of consumers with no preference by claiming, "An amazing $60 \%$ said $3 \mathrm{mg}$ Triumph tastes as good or better than $8 \mathrm{mg}$ Merit". ${ }^{76}$

The trial evidence included submissions by Philip Morris and RJR of 11 different types of consumer research, including: monadic product tests (for reactions to products in isolation); paired comparisons (testing against one another); a study measuring the importance of various attributes to various smoker segments; and four "communications tests", including the Philip Morris Ad Communications Test and three Batten, Barton, Durstine, \& Osborne (BBDO) copy tests. This indicates what was routine in the advertising of these cigarettes, as both Philip Morris and their ad agency BBDO had their own ad tests custom designed for frequent use, none of which have apparently been produced in litigation to date. ${ }^{77}$

\section{Barclay}

With the FTC yield data providing apparent accreditation, consumers were likely to perceive yield numbers as valid and meaningful, and so thought the industry. When B\&W brought the Barclay product to market in 1981, it did so with an ad campaign calling the product $99 \%$ tar free. The product's structure generated phenomenally low yield data in the FTC test. This caused alarm among B\&W's competitors, who petitioned the FTC for help, and in doing so disclosed their awareness that the FTC testing procedure was flawed and the yield data invalid for human smokers.

"This generation of products, or the next, could easily be products which will deliver NO 'tar' or nicotine when smoked by the FTC method, and yet when smoked by humans essentially be unfiltered cigarettes. Such products could (and would) be advertized [sic] as 'tar-free', 'zero milligrams FTC tar', or the 'ultimate low-tar cigarette', while actually delivering 20-, 30-, 40-mg or more 'tar' when used by a human smoker! They will be extremely easy to design and produce ... Such cigarettes, while deceptive in the extreme, would be very difficult for the consumer to resist, since they would provide everything that we presently believe makes for desirable products: taste, 'punch', ease of draw and 'low FTC tar'" [emphasis in original].$^{78}$

\section{Carlton}

A very desirable brand image was created for Carlton, especially by ads promoting Carlton in a hard box, emphasising its very low machine yield numbers (fig 11). Unfortu- nately, consumers purchasing Carlton in the store typically acquired soft packs. Although consumers might well have expected that they were getting the identical product in a different box, it was in fact a very different product.

"FTC's present system further contributes to consumer deception because it allows some cigarette companies to promote heavily a 'box' brand, without adequately distinguishing it from the soft pack of the same brand name, which delivers considerably more 'tar'. In fact, however, the companies produce such a small volume of the box brand as to make it a phantom brand that is rarely found in the marketplace. On the other hand, the soft-pack version bearing the identical brand name and package design but testing at a considerably higher 'tar' level, is the version readily available to the consumer" [emphasis in original]. ${ }^{79}$

\section{Re-examining smoker psychology}

Consumer research sought an ever more subtle understanding of smokers' psychology. RJR commissioned in-depth psychological research from Social Research, Inc in 1982 to closely compare the smokers of Vantage and Merit on the basis of their smoking histories, beliefs about the filter, and other responses to advertising, and their personalities. In-depth interviews delved into the psychological subtleties of respondents with detailed discussion centred on their comparative personality structures.

"As personalities, Vantage smokers seem more complex and more colorful. Overall, they have an upbeat attitude toward life, but in their eager openness they can reveal that they also harbor some less conventional tendencies, experiences and fantasies. Control, decisiveness and independence are important to Vantage people. They want to believe that they are their own person, someone who is self-made and self-taught. They boast about their reservoir of inner strength that gives them the self-confidence to meet life head-on". ${ }^{80}$

"Merit smokers are more conventional. They are not ordinary or humdrum, but their personalities are not as multi-dimensional. Their self-assurance operates up to certain limits; they avoid going beyond these limits for fear of losing control. They do not have as strong a sense of self. They count on others for help and guidance. Being less fiercely independent, they are more people oriented, more responsive to established values and standards" ${ }^{80}$

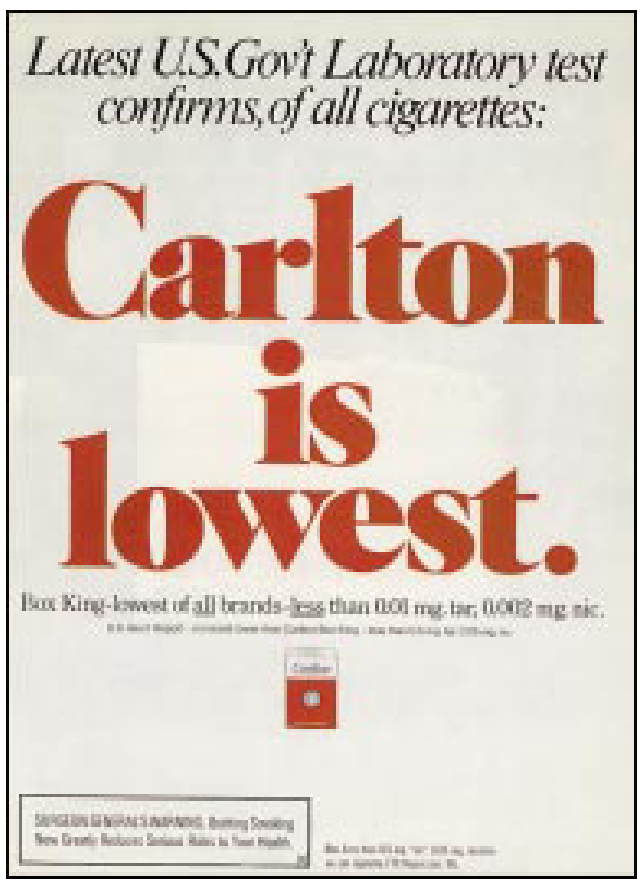

Figure 11 Carlton Box "phantom brand" (1985). 


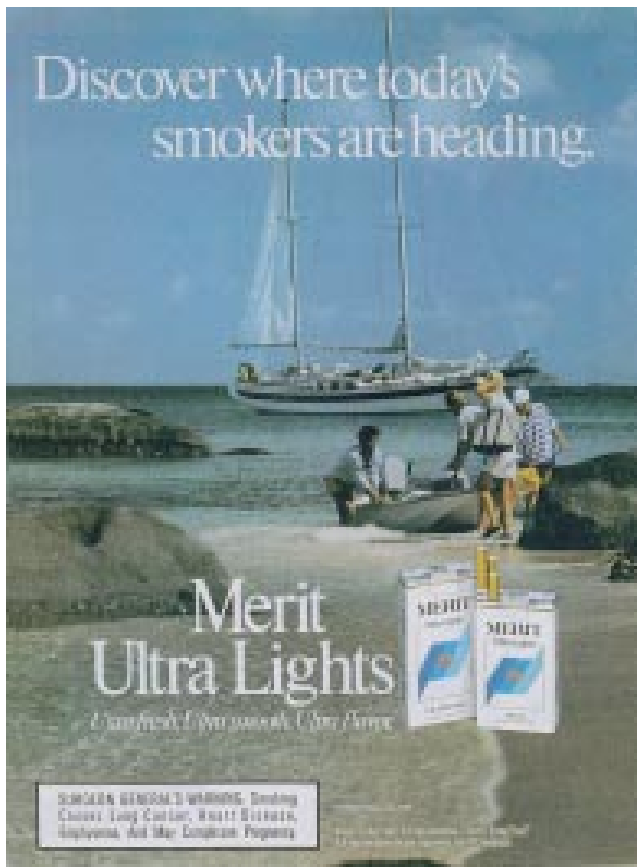

Figure 12 Merit Ultra Light "sea" campaign (1986).

Philip Morris, by the mid 1980s, was thinking about smokers as grouped into four segments: "Denier/Dedicated Smokers; Imprisoned Smokers/Compensators; Stubborn/ Resentful Smokers; and 'Closet' Smokers". Because all smokers were beleaguered by changing public norms about smoking, Philip Morris saw it as essential that advertising maintain and reinforce smokers' self perceptions. "The issue today is social acceptability. Tell me it is all right for a person like me to smoke. Tell me I am not personally offensive or unlovable because I smoke. Tell me I am not a social outcast because I smoke. Tell me smoking is not the most crucial choice in my life. Tell me I am not different from every one else just because I smoke. Give me positive role models ... Tell me my career and future are not jeopordized [sic] when I smoke that I will not be viewed as a nervous, anxious person with 'a bad habit;' that I can smoke and still be 'dressed for success'" [emphasis in original $].{ }^{81}$

\section{Picturing lifestyles}

Merit Ultra Lights

When Merit Ultra Lights were introduced in 1983, the advertising programme had an $\$ 80$ million media budget, not even accounting for retail promotional efforts. This advertising featured imagery of large sailing ships in what was termed the "sea" campaign (fig 12). The executions not only showed young people in an enviable, carefree, affluent lifestyle and a pristine environment, they also were careful to avoid any suggestions of danger. "[I]n 1983, we adopted the sea campaign ... First, to create an identity for Merit as the taste brand of low tars, and second to create an image for the brand which could be extended into promotions and retail materials ... we showed young people on pleasure boats enjoying their leisure time and smoking Merit. We deliberately tried to avoid dangerous looking water" ${ }^{82}$

\section{Vantage}

Images and ad copy had to be carefully selected, lest the ads reinforce fears rather than offer reassurance. In 1980, one Vantage ad made direct reference to "what you may not want" from a cigarette, only to discover that it alarmed some readers about cancer. "The fact that a Vantage ad dares to raise the issue of 'what you may not want' generates defensiveness

\section{To smoke or not to smoke.}

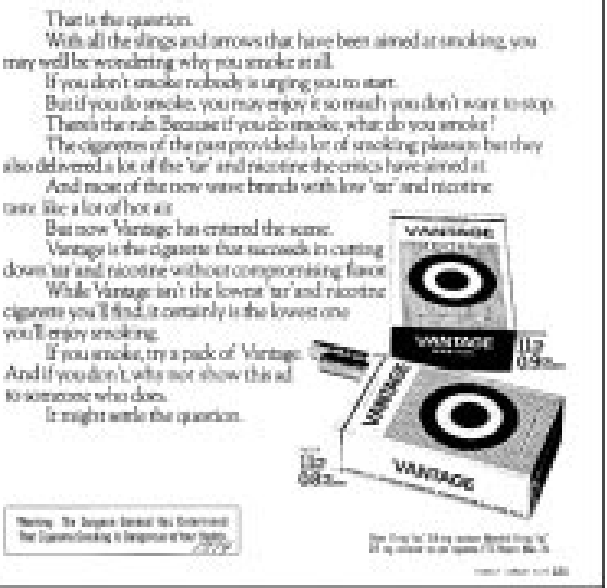

Figure 13 Vantage "To smoke or not to smoke" (1974).

toward smoking in general, and a feeling of discomfort. The reference to the taste of Vantage is lost; overpowered by the implications of tar, nicotine and cancer". A Vantage ad headlined "To Smoke or Not to Smoke" ran in both the US and Canada (fig 13). It stated that "Vantage is the cigarette for people who may have second thoughts about smoking and are looking for a way to do something about it". According to a RJR operational plan, the basic strategy was "positioning Vantage as the only contemporary choice for intelligent smokers". ${ }^{83}$

By 1986, Vantage was targeting a younger audience and sought to create an image of being "energetic, action oriented" (fig 14). Because "the appeal is purely visual, making the photography the most critical element of almost every campaign", they hired a photographer to "bring out the high energy and supersaturated color we wanted . . . [in] a bold graphic statement". The campaign showed solo "athletes involved in risky, high action, non-team sports ... the ads suggest VANTAGE smokers lead high energy life styles" ${ }^{84}$ The preshoot planning took months to scout location and select talent. The photographic shoot required a staff of 25 , working over three tightly scheduled days, starting at dawn, and shooting from helicopters. All models wore red to emphasise pack colours.

\section{DISCUSSION}

\section{The value of official ratings}

Some members of the industry have long found the appearance of governmental vetting to be a desirable factor usable in advertising. The federal government adoption of a "uniform and reliable testing procedure" consistent with the methodology of Philip Morris also seemed beneficial to Philip Morris. Philip Morris foresaw in 1964 that such test results could be used in advertising copy, as they communicated that an official government agency had vetted the product(s) as well as possibly providing data of competitive advantage. "Apart from possible legal requirements, such a policy would enhance advertising opportunities" ${ }^{85}$

More recently, B\&W saw the benefit to them, even if not to the public, in government evaluations and rating procedures. While the industry preferred to go unregulated, regulation 


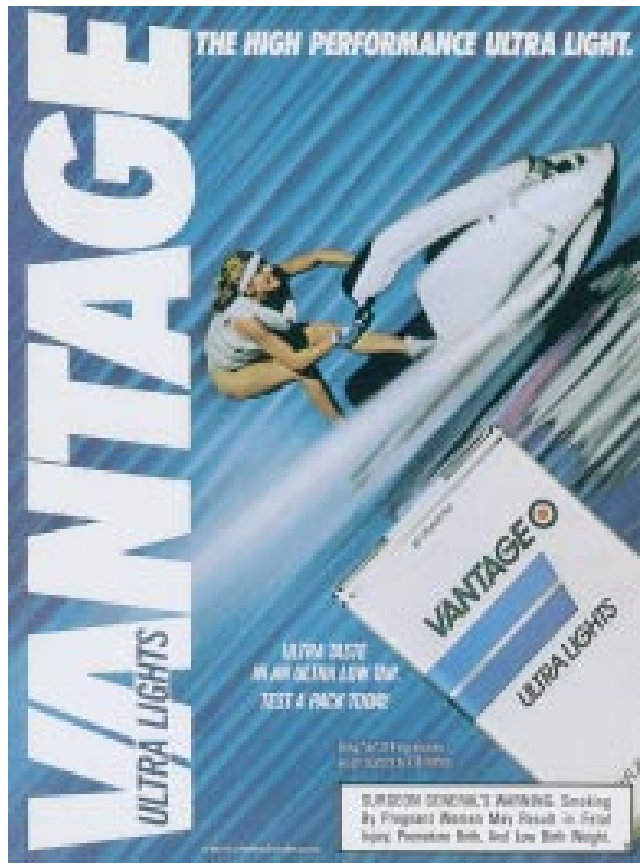

Figure 14 Vantage "energetic action" photography (1987).

offered some benefits, namely prospects for greater stability and the appearance of governmental approval of their products by official testing procedures ("for example, by capitalizing on official tar and nicotine ratings in cigarette advertising") ${ }^{86}$

The promotional value of the FTC data indicates that it is in the industry's self interest to protect the credibility of the FTC procedure. "Inherent limitations of the FTC cigarette testing program, and borderline low-'tar' advertising practices resulting from the way the test results are reported have contributed to substantial consumer confusion and misunderstanding. This situation threatens to erode public confidence in both the FTC's test reports and the industry's advertising claims ${ }^{\prime \prime}{ }^{87}$

\section{Poor information, but rich imagery}

Cigarette advertising is notoriously uninformative, with characteristic forms using veiled health implications and pictures of health along with vague promises of taste and satisfaction. ${ }^{88}$ Occasionally ads for new technological developments called attention to the filter design with allusions to its effectiveness, yet nearly always remained unspecific about what constituents of tobacco or its smoke were being filtered and what health/safety consequences were warranted. Only the machine yield tar and nicotine information is given, and presented as if rich with implications. For example, smokers are now encouraged to "start thinking about number 1 " and use Carlton Ultra Ultra Light (fig 15).

\section{Consumer ignorance}

The cigarette industry has not voluntarily utilised advertising to inform consumers in a consistent and meaningful way about any of the following: (1) the technologies employed in fabricating the products; (2) the constituents added in the manufacturing processes; (3) the residues and contaminants that may be present in the combustible column; (4) the constituents of smoke that may be hazardous; (5) the addictiveness of nicotine; or (6) the health risks to which its regular consumers and anyone surrounding them are inevitably exposed. Rather, advertising for low yield products has relied on pictures of health and images of intelligence, misleading consumers into believing that filtered products in general, and low tar products in specific, are safe(r) relative to

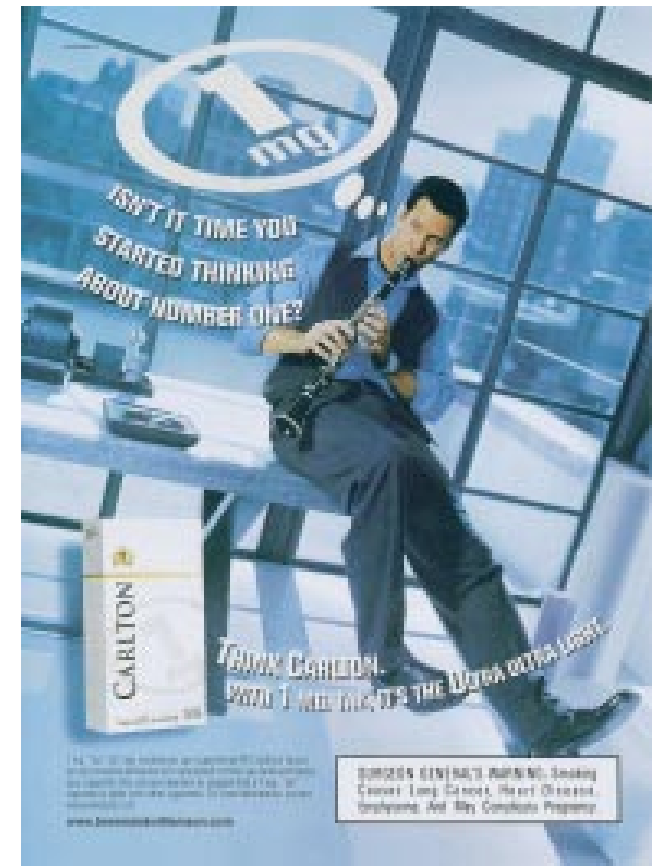

Figure 15 Carlton "Thinking about Number 1" (1999).

other brands. Thus, it is not surprising that most consumers show ignorance of even the most basic characteristics of the smoke they consume.

\section{Marketing/advertising works}

While the technological means to produce low yield products might seem important, to industry insiders it was the marketing sophistication that was even more crucial in determining the relative success of various firms. The chairman and CEO of Philip Morris defended advertising eloquently within a trade ad. "Those of us in the business of building brands don't have to be sold on the importance of advertising or on the necessity for advertising. For me, there is still nothing more exciting in business than to watch effective advertising work its magic in the marketplace. For when a brand is acknowledged and accepted by the consumer, it becomes something much more than what it really is . . . we invest $\$ 2$ billion annually in advertising. It's worth every penny. For we believe that a strong brand gives the consumer another whole set of reasons-emotional and personal— to act" ${ }^{89}$

\section{CONCLUSIONS}

We have reviewed multiple tobacco industry documents from all of the major US firms and validated and elaborated upon these with information from marketing trade sources. Our review reveals the importance of marketing and advertising to the vitality of this industry, and the many means used to create an appearance of healthfulness for their cigarette products, especially those with nominal low yields. To summarise:

1. Nicotine is a design feature of cigarette products, and an essential design feature (a "sine qua non"). Corporate documents reflect the industry's fear of consumers becoming weaned from smoking if not maintained with sufficient nicotine. Products which fail to deliver adequate nicotine satisfaction and "taste" experience risk being rejected by consumers.

2. Consumer knowledge, beliefs, attitudes, opinions, and behaviour have been routinely and extensively studied by the industry and the firms it has hired (that is, market research firms, motivation researchers, and ad agencies). 
3. Health concerns of a serious nature have been present among some smokers since at least the 1950s. Women, older, and more highly educated smokers have long been more likely to manifest health concerns. The ramifications of these health concerns are anxieties, conflicts, shame, and guilt leading to a need for reassurance from advertising.

4. In the 1950s, the promotion of filters provided consumer reassurance with very explicit verbal representations about the health protection being offered. Once the nominal purpose of filtration was well understood by the consumer public, the healthfulness of filters was represented in more implicit means, using thinly veiled language (for example, "hospital white" filters, "Alive with Pleasure") and visual "pictures of health" (that is, lively behaviour and/or pristine environments).

5. The "image" or "illusion of filtration" is essential to the selling of cigarettes, whereas the fact of filtration is not. Consumer (smoker) opinion and perceptions are what governs their behaviour, not the medical or technological facts known to manufacturers and experts.

6. Many deceptive practices have been employed over the years, some continuing to the present, that foster and perpetuate the illusion that particular cigarette brands and forms are relatively healthy. These tactics include:

(a) Using cosmetic ineffective filters. Some brands relied on the credibility of filters established by the pioneering brands, and offered products with filters that were essentially cosmetic, without notable efficacy.

(b) Using medicinal menthol. Menthol was introduced into some products to capitalise on its "pseudo-health" benefit, a consumer perception derived from experiencing menthol elsewhere in the medicinal context of cough and cold remedies.

(c) Loosening filters. Once established in the public's mind as having effective filtration, Kent offered several successive generations of product in the 1950s and 1960s that were seemingly "new and improved", yet in fact delivered ever more tar and nicotine.

(d) Using high tech imagery. New filters were presented that seemed to be the fruits of scientific research (that is, technologically innovative), such as charcoal filters, dual filters, chambered filters, recessed "safety zoned" filters, gas trap filters, etc. Promotions for these products rarely specified the hazardous elements being filtered.

(e) Using virtuous brand names and descriptors. Brands were given names to imply state-of-the-art technology and/or a virtuous product (for example, Life, Merit, Now, True, or Vantage). Product variations became described in technically meaningless, but seemingly virtuous, descriptors like "Mild", "Ultra", "Light", or "Super-Light".

(f) Adding a virtuous product to a product line. Some product lines had wide ranging tar and nicotine deliveries in the same brand family. The best of these was used for advertising purposes to reassure consumers while selling other product varieties. When the best product variant was featured in ads but rarely sold in the stores, it was described by competitors as a "phantom brand".

(g) Fooling the machines and using the data to fool smokers. Filters and cigarette papers were developed starting in the 1950s which "air conditioned" the smoke, diluting the smoke column with side stream air. When smoked by machines, as in FTC tests, low tar and nicotine numbers resulted, desirable for promotional purposes, but higher yields were obtained by real people, desirable in satisfying nicotine addiction.

7. The testing of products by official government agencies, like the FTC, provides the industry with credibility, and data that proves useful for promotional purposes.

\section{What this paper adds}

Previous research has examined internal tobacco industry documents to provide summary evidence of the marketing and research agendas of various tobacco manufacturers. The widest attention has been directed toward the importance of youth as a "starter market".

This historical analysis of trade press and internal industry documents focuses on the development, intent, and consequences of US tobacco industry advertising for low machine yield cigarettes. Our analysis reveals that over the past 50 years advertisements of filtered and low tar cigarettes were intended to reassure the many smokers who were anxious about the health risks of smoking. The findings add credence to the claim that brand descriptors such as "Mild", "Light", and "Ultra-Light" are deceptive and misleading to consumers, and thus need to be addressed by public policy initiatives.

8. Low yield cigarettes were heavily promoted. Promotional programmes for cigarettes have been lavishly funded in general, with advertising in multiple media. A disproportionate amount of this funding promoted low yield products when they were introduced in the 1970s.

9. Little or no meaningful information is contained in cigarette promotion about the product, its ingredients and additives, the technology of filtration, the hazardous constituents of smoke, or the health consequences of smoking.

10. Consumer ignorance and confusion has been persistent over decades. While smokers that switch to low yield brands manifest faith in their relative healthfulness, few consumers know the true delivery characteristics of the brands they smoke. Even their general impressions are not too accurate.

11. Cigarette advertising addresses both the smoker's ego/ status needs, as well as the need for health reassurance. Successful advertising creates brand imagery which affects self perceptions and the social symbolism of smoking. Successful advertising also maintains the illusion of healthfulness, without being so obvious as to provoke anxieties and defensiveness, and sustains "faith and confidence in the smoking habit".

12. Marketing activities (that is, product design, packaging, PR, retail activities, etc) and advertising have proven essential to maintaining the financial vitality of the cigarette industry by maintaining the apparent vigour of the cigarette product.

13. Images have succeeded while facts have failed. Cigarette advertising has successfully created the "impression" or "illusion" of healthfulness, while relying primarily on visual images of lifestyles, implications of social status, and healthfulness. Consumers, with too few facts provided to guide them, cannot make truly informed decisions.

\section{ACKNOWLEDGMENTS}

Timothy Dewhirst is a recipient of a National Health PhD Fellowship from Health Canada/Canadian Institutes of Health Research.

Authors' affiliations

R W Pollay, T Dewhirst, University of British Columbia, Vancouver, BC, Canada

\section{REFERENCES}

1 Pollay RW. Promotion and policy for a pandemic product: notes of the history of cigarette advertising (US). Tobacco Litigator's Bookshelf 1989;4.7 TPLR:6.30-6.79.

2 Whelan EM. A smoking gun: how the tobacco industry gets away with murder. Philadelphia: Geo. Stickley, 1984:90.

3 Pollay RW. Filters, flavors . . flim-flam, too!: cigarette advertising content and its regulation. Journal of Public Policy and Marketing 1989;8:30-9. 
4 Johnston Jr ME. Market potential of a health cigarette. Special report no. 248. Philip Morris document June 1966:16. Bates No. 1000338663

5 Federal Trade Commission. Trade regulation rule for the prevention of unfair and deceptive advertising and labelling of cigarettes in relation to the health hazards of smoking and accompanying statement of basis and purpose of rule. Washington DC: FTC, 22 June 1964: 72.

6 Pepples E. Industry response to cigarette health controversy. Brown \& Williamson document 4 February 1976:2. Bates No. 779063894 available at http://www.library.ucsf.edu/tobacco/docs/html/2205.01/ 2205.01.2.html

7 Oxtoby-Smith Inc. A psychological map of the cigarette world. Prepared for Ted Bates and Brown \& Williamson. August 1967:26. Produced in Texas AG litigation, TAG \#777152146.

$8 O^{\prime}$ Keefe AM, Pollay RW. Deadly targeting of women in promoting cigarettes. Journal of the American Medical Women Association 1996:51:67-9.

9 Abrams T, Crist P, Kaczynski S, et al. Undated attorney work product. Prepared for Jones, Day, Reavis \& Pogue. Brown \& Williamson document. Bates No. 681879254/715.

10 Latimer FE. Cigarette advertising history. Brown \& Williamson document, 29 November 1976:5. Bates No. 680086043

11 Blatnik J. Making cigarette ads tell the truth. Harper's Magazine August 1958;217:45-9.

12 Chambers RL. U.S. cigarette history. Brown \& Williamson document, 21 September 1979: np. Bates No. $660110385-660110386$

13 Cunningham \& Walsh. Kool: 1933-1980. A retrospective view of Kool. Brown \& Williamson document 10 November 1980:9. Bates No. 676019314

14 Wakeham H. Smoking and health: significance of the report of the Surgeon General's committee to Philip Morris Incorporated. Philip Morris Research Center. 18 February 1964:8. Bates No. 1000335622

15 Johnston Jr ME. Market potential of a health cigarette. Special report no. 248. Philip Morris document June 1966: 1. Bates No. 1000338648

16 Oxtoby-Smith Inc. A psychological map of the cigarette world. Prepared for Ted Bates and Brown \& Williamson. August 1967:6, 14 23. Bates No. 777152126, 777152134, 777152143.

17 Alex Gochfeld Associates Inc. The present competitive position of Pall Mall Gold 100's and Silva Thins: a motivational research study Prepared for The American Tobacco Company. March 1969.9. Produced in Minnesota litigation, available at http:// www.bw.aalatg.com

18 Kieling RF. Implications for Kent. Director of Market Research. 31 August 1964:3-5. Bates No. $01140938-01140940$.

19 Johnston Jr ME. Market potential of a health cigarette. Special report no. 248. Philip Morris document June 1966:1-2, 5. Bates No. $1000338648,1000338649,1000338652$

20 Teague CE. Proposal of a new, consumer-oriented business strategy for RIR tobacco company. 19 September 1969:9-10. Bates No. 500915709-500915710

21 Anon. The product in the early 1980s. BAT Co document. 29 March 1976:2. Bates No. 110069975

22 Tindall JE. A new low delivery segment. Philip Morris USA Research Center. 22 May 1973:16. Bates No. 1002473802

23 Schori TR. Tar, nicotine and smoking behavior. Philip Morris USA. Research Center. November 1971:1. Bates No. 2062951584

24 Teague CE. Research planning memorandum on the nature of the tobacco business and the crucial role of nicotine therein. RJR document. 14 April 1972:3 Document or Bates No. 7578

25 Dickerson JP, Woods JD. Low "tar" cigarette prototype. RJR Inter-office memorandum. 19 February 1975:2. Bates No. 504208704.

26 Fitzgerald CW, Senkus M, Laurene A, Kecseti FM (presenters). New product/merchandising directions: a three year action plan. RJR document. 19 August 1976:1, 38. Bates No. 501143244 501143259.

27 Oldman M. Products/consumer interaction. BAT Co document. 19 May 1981:2. Bates No. 109383263

28 Anon. Purite filter. Brown \& Williamson document 1977:4, 13. Bates No. 777076771, 777076780.

29 Marketing and Research Counselors, Inc. What have we learned from people? A conceptual summarization of 18 focus group interviews on the subject of smoking. 26 May 1975:9. Bates No. 670171228.

30 Oxtoby-Smith Inc. A psychological map of the cigarette world. Prepared for Ted Bates and Brown \& Williamson. August 1967:24-5. Bates No. 777152144-777152145.

31 DeGarmo Inc. Research Department. Conclusions and implications of True porffolio research. Prepared for Lorillard. August 1974: np. Bates No. 03374671 .

32 Hind JF, Fitzgerald CW, Ritchy AP. New brand orientation for Ogilvy \& Mather, Inc. RJR document. 10 August 1976:63. Bates No. 501143762

33 Marketing and Research Counselors, Inc. What have we learned from people? A conceptual summarization of 18 focus group interviews on the subject of smoking. 26 May 1975:2. Bates No. 670171221.

34 Anon. Merit history (script for slide presentation). Philip Morris document. 17 August 1990:13-14. Bates No. $2500114499-2500114500$

35 Anon. Young adult smoker life styles and attitudes. Prepared for Brown \& Williamson. 1974:2, 7. Bates No. 680109281, 680109286

36 O'Toole JE. The trouble with advertising. New York: Chelsea, 1981:94-5.

37 The Roper Organization Inc. A study of smokers' habits and attitudes with special emphasis on low tar cigarettes. Prepared for Philip Morris USA. May 1976:14. Bates No. 2022207319.
38 Kalhok AI, Short PL. The effect of restrictions on current marketing on marketing in the future. Brown \& Williamson document May 1976:8 Bates No. 680040475

39 Anon. Year 2000. BAT Co document. Exhibit 11,350, State of Minnesota and Blue Cross and Blue Shield of Minnesota v. Philip Morris, Inc, et al. 4 April 1979: 1. Bates No. 109883101.

40 Kalhok Al, Short PL. The effect of restrictions on current marketing on marketing in the future. Brown \& Williamson document May 1976:1 1 Bates No. 680040478.

41 Marketing and Research Counselors, Inc. What have we learned from people? A conceptual summarization of 18 focus group interviews on the subject of smoking. 26 May 1975:1-2, 5, 12-13. Bates No. $670171220-670171221,670171224,670171231-670171232$.

42 Anon. Concerned segment: long term strategic marketing analysis. RJR document. 27 March 1986:41. Bates No. 515112989.

43 Anon. The product in the early 1980s. BAT Co document. 29 March 1976:6. Bates No. 110069979.

44 John J, Wakeham H. Breakthrough of the high taste, low tar cigarette-a case history of innovation. Philip Morris Research Center. 1977:8. Bates No. 2024824163.

45 John J, Wakeham H. Breakthrough of the high taste, low tar cigarette-a case history of innovation. Philip Morris Research Center. 1977:13-14. Bates No. 2024824168-2024824169.

46 Anon. Merit history (script for slide presentation). Philip Morris document. 17 August 1990:4. Bates No. 2500114502.

47 Anon. Brand report 12: cigarettes. Media Decisions 1976;1 1:148.

48 Anon. Brand report 12: cigarettes. Media Decisions 1976;11:146.

49 Anon. Brand report 23: cigarettes. Media Decisions 1977:1 2:152.

50 Anon. Purite filter. Brown \& Williamson document 1977:1. Bates No. 777076768

51 Anon. Brand manager in the hot seat. Media Decisions 1978;13:68.

52 Anon. Brand report 23: cigarettes. Media Decisions 1977;1 2:154.

53 Porter JH. The last cigarette advertisement. New York State Journal of Medicine 1985:85:359.

54 Fitzgerald CW, Senkus M, Laurene A, Kecseti FM (presenters). New product/merchandising directions: a three year action plan. RJR document. 19 August 1976:91. Bates No. 501143279.

55 Fitzgerald CW, Senkus M, Laurene A, Kecseti FM (presenters). New product/merchandising directions: a three year action plan. RJR document. 19 August 1976: np. Bates No. 501143266

56 Crittenden A. $\$ 40$ million for a real smoke. The New York Times, 15 May 1977: Sec. 3, $1 \mathrm{ff}$.

57 Hind JF, Fitzgerald CW, Ritchy AP. New brand orientation for Ogilvy \& Mather, Inc. RJR document. 10 August 1976:40. Bates No. 501143747.

58 Anon. Camel Lights marketing background. RJR document: np Bates No. 505254243-505254283

59 Anon. Winston Light 100's promotion plan. RJR document: 261. Bates No. 503406611

60 Anon. Brand report 23: cigarettes. Media Decisions 1977;12:150.

61 Anon. Triumph planning seminar: competitive advertising. Lorillard document. 25 February 1980: np Bates No. 89923112.

62 Anon. Purite filter. Brown \& Williamson document 1977: 14. Bates No. 777076781.

63 Cunningham \& Walsh. Kool: 1933-1980. A retrospective view of Kool. Brown \& Williamson document. 10 November 1980:55. Bates No. 676019361

64 Koten J. Tobacco marketers' success formula: make cigarets [sic] in smoker's own image. Wall Street Journal, 29 February 1980:22.

65 Anon. What are the obstacles/enemies of a swing to low "tar" and what action should we take? Exhibit 26,185, State of Minnesota and Blue Cross and Blue Shield of Minnesota v. Philip Morris, Inc., et al. 2 July 1982:2-3. Bates No. 680592165-680592166.

66 The Roper Organization Inc. A study of smokers' habits and attitudes with special emphasis on low tar cigarettes. Prepared for Philip Morris USA May 1976:3, 19-20. Bates No. 2022207308 2022207324-2022207325

67 Goldstein/Krall Marketing Resources, Inc. A qualitative exploration of smoker potential for a new entry in the ultra low tar market category (two focused group interviews). Prepared for Philip Morris. January 1979: np Cover page Bates No. 2040066741, available at http:// www.smokescreen.org/tdoc/ dispPage....0\%22tar\%22\&HideComment=YES\&parent|D=38 252

68 Anon. R\&D/marketing conference. BAT Co document 1985:9, 13 Bates No. 100501589, 100501593

69 Goldstein/Krall Marketing Resources, Inc. A qualitative exploration of smoker potential for a new entry in the ultra low tar market category (two focused group interviews). Prepared for Philip Morris. January 1979:12 Bates No. 2040066754

70 Spears A. Untitled (re: costs of making tobacco products). Lorillard document. Exhibit 14,009, State of Minnesota and Blue Cross and Blue Shield of Minnesota v. Philip Morris, Inc, et al. 13 November 1973: 2-3. Bates No. 80634636-80634637

71 Fitzgerald CW, Senkus M, Laurene A, Kecseti FM (presenters). New product/merchandising directions: a three year action plan. RJR document. 19 August 1976: 46 Bates No. 501143263.

72 Hind JF, Fitzgerald CW, Ritchy AP. New brand orientation for Ogilvy \& Mather, Inc. RJR document. 10 August 1976:60. Bates No. 501143760

73 Brown \& Williamson. Partial document re: why people start and continue smoking, smokers, needs, reasons and brand imagery. Brown \& Williamson document. No Date Cited: np. Produced in Texas AG litigation, TAG \#67901 $1027 \mathrm{ff}$ 
74 Latimer FE. Cigarette advertising history. Brown \& Williamson document. 29 November 1976:1-2. Bates No. 680086039-680086040.

75 Short PL. Smoking \& health item 7: the effect on marketing. BAT Co document. Exhibit 10,585, State of Minnesota and Blue Cross and Blue Shield of Minnesota v. Philip Morris, Inc, et al. 14 April 1977:1, 3. Bates No. $100427792,100427794$.

76 Anon. Philip Morris, Inc. v. Loew's Theatres, Inc., 511 F. Supp. 855 (SDNY 1980).

77 Zoler JN. Research requirements for ad claims substantiation. Journal of Advertising Research 1983;23:9-15. [This provides copies of the ads in question. Zoler was Director of Marketing Research for Philip Morris.]

78 Reynolds JH, Norman AB, Robinson JH. Possible consequences of failure of the FTC to act against the Barclay cigarette filter and its mimics. RJR Interoffice Memo. 4 March 1982:1. Bates No. 503670658.

79 Pepples E. Low-"tar" cigarette advertising and the FTC cigarette testing program: a time for re-examination. Brown \& Williamson Memo. 9 June 1982:4. Document or Bates No. 41342.

80 Levy SJ, Robles AG. Vantage and Merit smokers. Social Research, Inc. (Prepared for RJR). April 1982:90. Bates No. 502097547.

81 Anon. Presentation to Hamish Maxwell. Philip Morris document. 19 November 1985. Bates No. $2023177690-2023177691$.

82 Anon. Merit history (script for slide presentation). Philip Morris document. 17 August 1990:9, 11. Bates No. 2500114503 , 2500114505
83 Pollay RW. Targeting youth and concerned smokers: evidence from Canadian tobacco industry documents. Tobacco Control 2000;9: 136-47

84 Kaplan M. Inside advertising: perfect match. American Photographer October 1986: 100-2.

85 Wakeham H. Smoking and health: significance of the report of the Surgeon General's committee to Philip Morris Incorporated. Philip Morris Research Center. 18 February 1964:6. Bates No. 1000335620.

86 Pepples E. Industry response to cigarette health controversy. Brown \& Williamson Memo. 4 February 1976:8. Bates No. 779063900 Available at http://www.library.ucsf.edu/tobacco/docs/html/ 2205.01/2205.01.5.html.

87 Pepples E. Low-"tar" cigarette advertising and the FTC cigarette testing program: a time for re-examination. Brown \& Williamson Memo. 9 June 1982:1. Document or Bates No. 41342.

88 US Department of Health and Human Services. Preventing tobacco use among young people. A report of the Surgeon General, 1994 Atlanta, Georgia: Public Health Service, Centers for Disease Control and Prevention, Office on Smoking and Health, 1994. (US Government Printing Office Publication No S/N 017-001-00491-0.):179-84.

89 Miles M. 4 A's advertisement. The New York Times, 24 November 1992:16

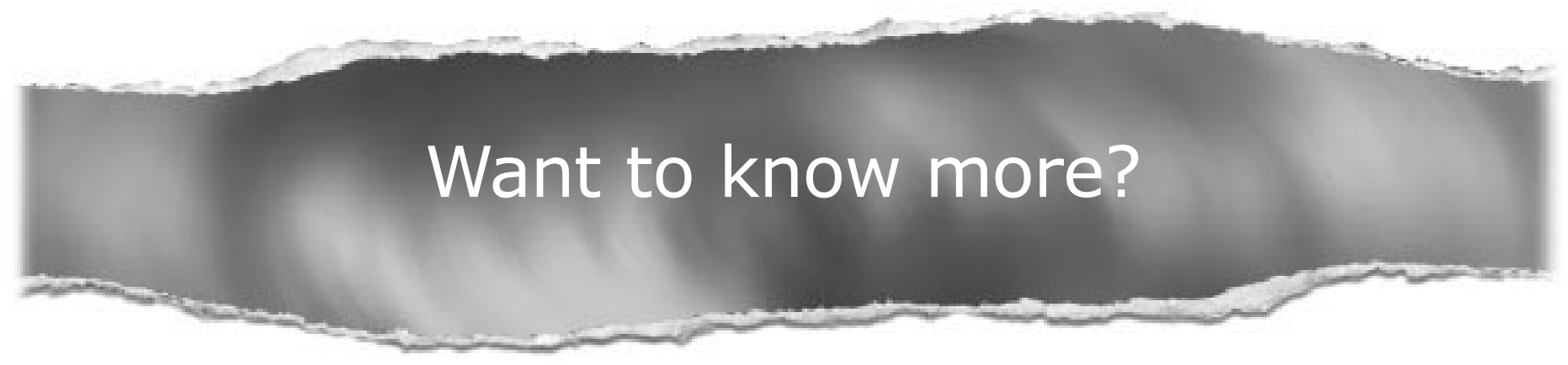

Data supplements

Limited space in printed journals means that interesting data and other material are often edited out of articles; however, limitless cyberspace means that we can include this information online.

Look out for additional tables, references, illustrations.

www.tobaccocontrol.com 